\title{
Measuring Governance to Achieve Sustainable Development: Promises and Challenges
}

Link to publication record in Manchester Research Explorer

\section{Citation for published version (APA):}

Malito, D., Umbach, G., Savoia, A., \& Hulme, D. (2020). Measuring Governance to Achieve Sustainable Development: Promises and Challenges. In W. Leal Filho, A. Marisa Azul, L. Brandli, A. Lange Salvia, P. Gokcin Ozuyar, \& T. Wall (Eds.), Peace, justice and strong institutions: Encyclopedia of the UN Sustainable Development Goals Springer Nature.

\section{Published in:}

Peace, justice and strong institutions

\section{Citing this paper}

Please note that where the full-text provided on Manchester Research Explorer is the Author Accepted Manuscript or Proof version this may differ from the final Published version. If citing, it is advised that you check and use the publisher's definitive version.

\section{General rights}

Copyright and moral rights for the publications made accessible in the Research Explorer are retained by the authors and/or other copyright owners and it is a condition of accessing publications that users recognise and abide by the legal requirements associated with these rights.

\section{Takedown policy}

If you believe that this document breaches copyright please refer to the University of Manchester's Takedown Procedures [http://man.ac.uk/04Y6Bo] or contact uml.scholarlycommunications@manchester.ac.uk providing relevant details, so we can investigate your claim.

\section{OPEN ACCESS}


Measuring Governance to

Achieve Sustainable Development: Promises and Challenges

Debora V. Malito ${ }^{1}$, Gaby Umbach ${ }^{2}$, Antonio Savoia $^{3}$ and David Hulme ${ }^{3}$

${ }^{1} \mathrm{Xi}$ 'an Jiaotong-Liverpool University, Suzhou, People's Republic of China

${ }^{2}$ Robert Schuman Centre for Advanced Studies, European University Institute, Florence, Italy

${ }^{3}$ Global Development Institute and Effective

States and Inclusive Development Centre,

University of Manchester, Manchester,

Lancashire, UK

\section{Definitions}

SDG 16 on Peace, Justice and Strong Institutions targets the promotion of peaceful and inclusive societies, universal access to justice, and effective, accountable, and inclusive institutions. It defines (good) governance as a development goal and focuses on human rights and fundamental freedoms, the rule of law and equal access to justice, the fight against corruption and bribery, institution-building and decision-making processes, public access to information, and developing countries' participation in global governance institutions.
Governance is the exercise and effectiveness of state authority through political, economic, and administrative institutions. It includes the selection and control of executives, government capacity to formulate and implement policies, and respect for institutions governing state-citizen interactions. At global level, governance is qualified as "good" and "democratic" if transparency of the institutions exercising it is guaranteed.

Justice and the rule of law are defined by the $\mathrm{UN}$ as a governance principle that serves holding subjects and objects of governance accountable to laws. Equality before the law and an independent judiciary are essential to make the principle consistent with international human rights norms. Additional key factors of the principle are supremacy of law, accountability to the law, fairness in application, separation of powers, participation in decision-making, legal certainty, avoidance of arbitrariness, and procedural and legal transparency.

Securing peace and saving future generations from the threat and consequences of war are prominently enshrined in Chapter 1 , Article 1 of the Charter of the United Nations. They form the building blocks of the UN's peace-keeping and peace-building activities. 


\section{Introduction}

The SDGs place strong emphasis on "good governance" to achieve both peace and security for sustainable development. They explicitly state that "Sustainable development cannot be realized without peace and security; and peace and security will be at risk without sustainable development" (United Nations 2015 point 35). The 2030 Development Agenda also recognizes the need to "build peaceful, just and inclusive societies that provide equal access to justice and that are based on respect for human rights (including the right to development), on effective rule of law and good governance at all levels and on transparent, effective and accountable institutions" (United Nations 2015 point 35 ). The SDGs underline this governance-security nexus based on the insight that "negative costs of ineffective governance in terms of the loss of human lives, stunted human development, environmental degradation, and waste of financial and organizational resources are enormous" (Joshi et al. 2015, p. 286). Accordingly, pursuing the SDGs requires the upscaling and improvement of governance structures and systems within and across countries to guarantee development that is just, inclusive, and sustainable. Hand in hand with such systemic upscaling goes the need to assess and monitor a range of governance dimensions, including institutional quality and state capacity, across countries and over time.

Many academics and practitioners agree that there is a problem with the quality of contemporary measures of governance. Since the 1990s, scholars have widely contested the methodological soundness of indicators, such as the use of subjective data (Galtung 1998), and raised doubts about the simplicity, accuracy, and transparency of the operationalization needed in approximating the reality. Since the early 2000 s, scholars have also critically analyzed the relationships of power embedded in the construction and use of such metrics (Davis et al. 2012; Kelley and Simmons 2014; Cooley and Snyder 2015; Merry et al. 2015; Malito et al. 2018). This literature has contributed to framing the contemporary reflexive indicator culture (Bhuta et al. 2018) and to identifying its limitations. Many efforts have been undertaken to adjust them. Yet, both methodological and normative limitations persist. This chapter addresses a related, yet differently nuanced, question: To what extent do existing measures provide a robust analytical framework for the post-2015 development agenda?

Realizing SDG 16 of peaceful, just, and inclusive societies is one of the most ambitious and essential goals of the entire SDG agenda. Yet, as pointed out by the United Nations in the 2019 Sustainable Development Goals Report, not only "[r] ealizing the goal of peaceful, just and inclusive societies is still a long way off," but in recent years "no substantial advances have been made towards ending violence, promoting the rule of law, strengthening institutions at all levels, or increasing access to justice" (United Nations 2019, p. 57). Implementation challenges persist alongside methodological difficulties: as SDG 16 targets have been criticized for being too broad and hardly measurable (Bhargava and Little 2015), the Inter-Agency and Expert Group on SDG Indicators (IAEG-SDGs) has created a comprehensive Global Indicator Framework to review progress at the global level. The framework was adopted by the UN General Assembly in 2017 and further refined in 2019 (United Nations General Assembly 2019). Yet, investment in data collection has witnessed limited progress, consensus on indicators to monitor progress is still missing and measuring as well as monitoring SDG 16 governance goals present both technical and political challenges.

Technically, challenges arise due to issues of comparability and methodology of available indicators. To grasp the breadth of the governance concept, governance measures consider a broad range of aspects of political steering, regulation, epistemic community-building, policy-learning, and knowledge-sharing. They inter alia focus on the quality of democracy and its institutions, the functioning and quality of public administrations, aspects of state capacity, or the rule of law. One of the main challenges when measuring SDG 16 is that the SDG's concept of governance is implicitly and not clearly operationalized as a development goal, and nationally adopted approaches and 
patterns hence differ hugely. Measuring SDG 16 governance targets yet implies the assessment of the quality and performance of governance, i.e., the evaluation of the compliance of states and their governance structures with clearly established paradigms and norms of governance.

Politically, the chapter argues that challenges arise because of the perceived legitimacy and alleged objectivity of any measurement exercise, given that the nature of producers and funders of existing measures may reflect power imbalances across states rather than shared notions of good governance standards. While strongly promoting the normative "good governance" approach within the global development agenda, concerns have emerged about the overarching acceptability and practical feasibility of existing governance measures, especially related to the monitoring of the SDG's governance goal. Existing measures of governance have created a circular feedback loop between measuring and the measured, as they not only measure what they are designed to measure but also define and frame what they should measure. Any selected SDG indicator defines a desired normalcy and highlights unfavored deviancy; they hence codify political agendas. Measuring the progress made towards the SDG is hence not just about assessing performance, it is also defining and creating universal norms. The decision on which SDG indicators to select is thus not merely a technical-methodological decision, it is part of the framing of the SDG's political agenda and of the future of development itself. In the same vein, deciding not to measure a particular phenomenon creates reality through exclusion and prioritization (Umbach 2019). As there is not a common widely accepted definition of governance, but rather a hegemonic one, the concrete operationalization of governance for measuring, the design and legitimacy of measurement tools and their application remain contested.

While the quality and the power of governance measures have been widely analyzed, the impact of political economy factors on the supply (and quality) of governance metrics has received so far little systematic attention. To contribute to the latter, the chapter proceeds as follows. First, it discusses the idea of governance as a development goal and its measurement. Then it illustrates the choices faced when measuring the governancerelated aspects of SDG 16. Finally, it concludes by highlighting the importance of future research looking into the political economy of measuring governance to improve the understanding of the possibilities and limits of the SDG's "good governance" approach.

\section{Measuring SDG 16: A Framework}

SDG 16 officially anchors governance within the global development agenda. It defines governance as a development goal and takes up core elements of the normative "good governance" discourse, establishing them as global goals for the future development of governance structures within and across states. Although strongly promoting such a normative "good governance" approach, SDGs, and SDG 16 in particular, remain vague about what governance means. SDG 16 mentions the term "global governance" when framing target 16.8 ("Broaden and strengthen the participation of developing countries in the institutions of global governance"), but for the rest, a clear-cut definition of governance is not provided. The following section therefore first considers the conceptual challenges that the idea of governance poses. This provides the backdrop for discussing measurement challenges with reference to the SDGs in the final part.

The governance concept reflects the impact of globalization and interconnectedness on the extension of political structures and arenas beyond the nation state (Zumbansen 2012). The "integration of state structures and political processes across political levels [...] steadily impacts on the division of competences and interaction patterns of different political institutions, levels, and actors" (Umbach 2017, p. 47; see Jachtenfuchs and Kohler-Koch 2003, p. 22). The term governance is usually employed to connote such new forms of rule without formal government (Rosenau and Czempiel 1992) as "a new way of making politics" (Levi-Faur 2012, p. 1) marked by a multiplicity of governing actions, actors, mechanisms, and structures. According to 
Levi-Faur (2011), governance can be conceptualized as a structure (institutions), process (dynamics and functions in policy-making), mechanism (institutional procedures), or strategy (manipulation of the institutional design) of policy- and decision-making. The concept implies the emergence of interdependent problem-solving structures, actors, and spaces that increase access points to decision-making, and create new functional political arenas, no longer exclusively linked to a specific territory or nation-state. As "a theoretical rapprochement to the complexity of political interactions within ... multilevel, multilayered and multitiered political system[s]" (Umbach 2009, p. 45 f.), the term remains vague: there is no commonly accepted definition of what governance is and implies. What follows is that it is hard to measure, since there is a discrepancy between the analyst's observed measure and the full concept they would like to capture, and thus the practice of measurement invariably requires proxies to assess the quality and performance of different governance components and features.

Adding more complexity to the debate, ideas of "good governance" have become prominent across institutional discourses, especially within the development policy debate (Smith and Brassett 2008). "Good governance" is perceived as the key ingredient for accountable political performance, efficient public affairs, and transparent organization of political power-citizen relations. It is seen to form the basis for transparent politics based on accountable administrations, sustainable regulation, high capacity levels, and low levels of corruption (see Andrews 2008; Doornbos 2001; Grindle 2004; Rotberg 2014; Rothstein 2012). "Good governance" requires efficiency, transparency, and accountability of political processes, actors, as well as institutional practices, and targets an increase in the representative character of governments, participation, ownership, and formal control in decision-making (Doornbos 2001). Concrete "good governance" characteristics aim to improve democratic institutions and embrace a long list of different normative elements, such as protection of human rights, nondiscrimination before the law and impartial judicial processes, transparent and accountable public administrations and agencies, subsidiarity and public participation, as well as deliberation. Due to such diversity, operationalizations of "good governance" are contested because of their practicability and often criticized as unrealistic (Grindle 2004, p. 526). It is in this context that policy-makers and researchers need to evaluate progress on governance as a development goal.

This implies that measuring the SDGs relies on inevitably imprecise measures and approximations of a diverse reality. Therefore, embarking on any exercise of setting and monitoring governance-related development goals requires careful stocktaking of existing measures to bundle resources and make the best possible use of existing established instruments.

So, what are available measures that could inform assessing and monitoring progress towards governance-related goals within SDG 16? Different options of measuring governance revolve around the division between input-/ rules-based and output-/outcome-focused perspectives. The input perspective defines governance as institutional context, as a "form of social order" (Börzel 2005, p. 617), pointing at the essential role of structures and processes, as well as the strategic interaction of different political and societal actors within certain institutions. In general, input-based measures assess the "structural and management characteristics of governments" (Andrews 2008, p. 381) by evaluating, for instance, existing political institutions, public administrative procedures and legislation, or measures enacted to control manage/human resources, infrastructure, or corruption (Andrews 2008; Fukuyama 2013).

The alternative output camp highlights that "governance is what governments do" (Rotberg 2014), as governments' capacity and achievements are central to measure the quality of governance. Fukuyama defines governance as "a government's ability to make and enforce rules, and to deliver services, regardless of whether that government is democratic or not" (Fukuyama 2013, p. 350). Normative aspects of "good governance" are not central to this output-/outcome- 
focused perspective, giving more credit to the capacity of governments to implement policies and deliver results (such as literacy rates, life expectancy, completed court cases, or the length of administrative proceedings).

As a result of different governance measurement conceptualizations, a series of challenges emerged. Table 1 offers a schematization. First, the use of subjective data and highly normative measures generated a reliability problem. Many aggregate indexes, for instance, the World Bank's Worldwide Governance Indicators (WGI) or the International Country Risk Guide (ICRG), privilege the use of subjective data, often relying on expert or business community views. In particular, the ICRG index, which has been frequently used in empirical studies on governance and development, is based on the aggregation of measures such as the "rule of law," "corruption in government," and "bureaucratic quality" provided by Political Risk Services. This is a commercial organization assessing political and economic risk, whose indicators' representativeness is biased towards the views of the business community and whose methodology does not provide an explicit discussion of the underlying concepts that the indicators rate. The use of subjective data certainly seeks to address the "cognitive deficit" that sees governance as an "intangible" concept (Malito 2018), but due to their innate subjectivity, perception-based indicators remain biased in neutrally representing the phenomena under observation (Galtung 1998). Second, many measures tend to focus more strongly on normative aspects of "good governance." As a result, metrics are often used to evaluate developing countries' governance features, viewed to be "either instrumental (they lead to development outcomes we care about) or intrinsic (they are worth doing in and of themselves)" (Holt and Manning 2014, p. 726) in promoting developmental goals. An "intrinsic" approach assumes "democracy and good governance ... [to be] mutually supportive" (Fukuyama 2013, p. 350) and prioritizes measures that capture the nature of state-society relations, or of the degree of state legitimacy and accountability. Measures of legal capacity, transparency, accountability, and administrative quality have indeed received more attention, even within the SDGs framework. An instrumental view of measuring good governance prioritizes measures of both material and nonmaterial dimensions of economic development, such as state capacity. Such an output/outcome-focused perspective presupposes that governance has an impact on economic development, which is subordinated to the administrative and legal capabilities of the single states to generate such a process. However, as pointed out by Hulme et al. (2015), more attention has been paid to the accountability and transparency component, while bureaucratic capacity and legal infrastructure have not received the attention they deserve.

Third, existing governance measures face a comparability dilemma, across time and space, largely deriving from the fact that the use of subjective data limits the quality and quantity of data that can be consistently used and compared. Many of the existing measures therefore only include a limited number of countries. As noted by Hulme et al. (2015), measures that are robustly theorized, and hence better equipped to capture the administrative and legal dimensions of state capacity, are affected by empirical limitations, such as the lack of time-series data or limited country coverage, and so are unlikely to cover all those countries who adopted the SDGs. This is the case, for example, of the Quality of Government (QoG) Expert Survey or the measure "Bureaucratic compensation, career opportunities and meritocratic recruitment" formulated by Evans and Rauch's (1999, 2000), available only for a fraction of world countries, for a very limited timespan. Perception-based indicators have also been criticized for their failure to generate replicable data required for cross-countries comparisons. The WGIs, for instance, suffer a longitudinal deficit because the measures provided do not inform about trends in global averages: ranking and data sources are not comparable from year to year because the composition of the sample substantially changes over time. Cross-country comparisons are also affected by the disparity of sources available for each country. For example, the "Quality of Legal Structure and Security of 
Measuring Governance to Achieve Sustainable Development: Promises and Challenges, Table 1 Measuring governance as a development goal

\begin{tabular}{l|l}
\hline Measures' limitations & Measurement challenges \\
\hline \multirow{2}{*}{ Reliability } & Subjectivity \\
\cline { 2 - 2 } & Normativity \\
\hline Comparability & Country coverage \\
\cline { 2 - 2 } & Time coverage \\
\hline
\end{tabular}

Source: Own compilation

Property Rights Index," part of the Fraser Institute Index of Economic Freedom, is assembled over the years from different sources.

Available data about governance quality show an inevitable trade-off: changes in governance quality are long-term as they are closely interrelated with institutional changes. Many of the existing measures do not allow for capturing such long-term changes, and year-to-year monitoring might be ineffective. Moreover, many of the available measures do not have the timespan necessary for monitoring long-term processes. The monitoring of the post-2015 goals implies the establishment of a "start" date, the year 2005, that limits the choice of measurement options to suboptimal decisions between what is already available (Hulme et al. 2015). The WGIs are the measure that might provide such information with an adequate level of country coverage, but as outlined above are also amongst the most criticized measures for questions of legitimacy, comparability, and representativeness. More promising, instead, is the recent Varieties of Democracy dataset (V-Dem), presenting higher degrees on internal consistency (as shown in Boese 2019) and hence greater reliability in terms cross-country and temporal comparisons.

\section{The Challenge of Measuring and Monitoring Progress on Specific SDG 16 Targets}

The dilemma of measuring progress towards the SDGs revolves around opening (intra-)governmental decision-making to wider scrutiny. Yet, the reality of how governance is conceptualized, experienced, and exercised across time and space is dynamic, complex, and context-dependent. This particularism contradicts the universality of claims to knowledge, measuring, and authority in the governance discourse. Even though viewed through the seemingly neutral and objective lenses of statistics, measuring anchors in historically and socially constructed values, ideas, and norms. Finding politically acceptable dimensions of governance, which are consistent across countries and over time, is the real challenge of the post-2015 development goals.

The dual focus on reliability and comparability of contemporary measures helps assess the governance aspects of SDG 16 measurement, on the basis of metadata available for every target and their indicators (UNSTATS 2020). On the one hand, various elements of "good governance," government, governing and state capacity frame what SDG 16 sets out to achieve. As shown in Table 2, within SDG 16 targets, both input-/ rules-based and output-/outcome-focused perspectives resonate, even if the input perspective prevails. By reflecting the normative focus of strengthening "good governance," the prevalence of the input perspective might yet create both challenges and opportunities.

Both the implementation of and compliance with the SDG agenda are difficult to measure homogeneously across countries. The SDG process explicitly "recognise[s] that there are different approaches, visions, models and tools available to each country, in accordance with its national circumstances and priorities, to achieve sustainable development" (United Nations 2015 point 57). While agreement has been reached on the measurement of some SDG 16 targets (16.1, 16.2 ), in 2020, there is still work in progress on how exactly measuring others. The relative openness of how the targets are formulated plus the leeway for national differentiation in implementation leave room for diverse governance structures to emerge and/or persists while participating in the SDG process. The Statistics Division of the UN Department of Economic and Social Affairs (UNDESA), responsible for measuring and monitoring progress towards the SDGs, is fully aware of these obstacles. To avoid naïve "cockpit-ism" - 
Measuring Governance to Achieve Sustainable Development: Promises and Challenges, Table

2 Governance components of SDG 16

\begin{tabular}{|c|c|}
\hline $\begin{array}{l}\text { SDG } 16 \\
\text { Targets }\end{array}$ & $\begin{array}{l}\text { 16.1 Significantly reduce all forms of } \\
\text { violence and related death rates } \\
\text { everywhere (output/outcome) } \\
\text { 16.2 Ending abuse, exploitation, } \\
\text { trafficking, violence against and torture } \\
\text { of children (output/outcome) } \\
\text { 16.3 Promote the rule of law at the } \\
\text { national and international levels and } \\
\text { ensure equal access to justice for all } \\
\text { (input) } \\
\text { 16.4 By 2030, significantly reduce } \\
\text { illicit financial and arms flows, } \\
\text { strengthen the recovery and return of } \\
\text { stolen assets and combat all forms of } \\
\text { organized crime (output/outcome) } \\
\text { 16.5 Substantially reduce corruption } \\
\text { and bribery in all their forms (input and } \\
\text { output/outcome) } \\
\text { 16.6 Develop effective, accountable } \\
\text { and transparent institutions at all levels } \\
\text { (input) } \\
\text { 16.7 Ensure responsive, inclusive, } \\
\text { participatory and representative } \\
\text { decision-making at all levels (input) } \\
\text { 16.8 Broaden and strengthen the } \\
\text { participation of developing countries in } \\
\text { the institutions of global governance } \\
\text { (input) } \\
16.9 \text { By 2030, provide legal identity for } \\
\text { all, including birth registration (input) } \\
\text { 16.10 Ensure public access to } \\
\text { information and protection of } \\
\text { fundamental freedoms, in accordance } \\
\text { with national legislation and } \\
\text { international agreements (input) }\end{array}$ \\
\hline $\begin{array}{l}\text { Horizontal } \\
\text { Targets }\end{array}$ & $\begin{array}{l}\text { 16. a Strengthen relevant national } \\
\text { institutions, including through } \\
\text { international cooperation, for building } \\
\text { capacity at all levels, in particular in } \\
\text { developing countries, to prevent } \\
\text { violence and combat terrorism and } \\
\text { crime (input) } \\
\text { 16.b Promote and enforce non- } \\
\text { discriminatory laws and policies for } \\
\text { sustainable development (input) }\end{array}$ \\
\hline
\end{tabular}

Source: Own compilation based on United Nations General Assembly 2019

${ }^{a}$ Attribution to input and output/outcome perspective in brackets by the authors

that is "the illusion that top-down steering by governments and intergovernmental organizations alone can address global problems" (Hajer et al. 2015, p. 1652) - the UN acknowledge potential difficulties in measurement, recognize the missing data problem for several targets, and call for increased effort in data collection (United Nations 2015 point 57). At the same time, questions of comparability have surfaced related to the production and consistency of transnational aggregates.

Target 16.1 ("Significantly reduce all forms of violence and related death rates everywhere") puts the human-centered approach of the SDGs' development perspective center stage. Reducing violence and increasing human security is the starting point of SDG 16. The indicators selected include victims of intentional homicide, conflictrelated deaths, and population subjected to physical, psychological, or sexual violence. Indicator 16.1.4 ("Proportion of population that feel safe walking alone around the area they live") uses subjective data and operates with the concept of "fear of crime" that is filtered through individual perceptions, experiences, and cultural contexts. Data are retrieved from sample surveys among the general population and, most often, from crime victimization surveys. Although the concept is viewed as culturally robust by the data providers, the operationalization of the indicator differs across countries and an objective assessment of public security seems difficult by using perception-based assessment indicators (SDG Indicators Metadata-16-01-04). A comparative perspective is difficult because of missing data for many countries. Between 2000 and 2010, there were 63 countries that had at least 1 data point for this indicator.

Target 16.2 ("End abuse, exploitation, trafficking and all forms of violence against and torture of children") concentrates on children aged 117 years and young adults aged 18-29 years. It is measured focusing on physical punishment and/ or psychological aggression by caregivers, victims of human trafficking, and sexual violence. Indicator 16.2.2 ("Number of victims of human trafficking per 100,000 population, by sex, age and form of exploitation") is problematic as it misses the "dark number of crime, i.e. the number of victims non detected by the authorities ... [and] the number of detected victims per se doesn't 
monitor the level of trafficking of persons so interpretation of trends should be done with caution" (SDG Indicators Metadata-16-02-02). For indicator 16.2.3 ("Proportion of young women and men aged 18-29 years who experienced sexual violence by age 18 "), data is collected based "on different study methodologies and designs, definitions of sexual violence, samples and questions to elicit information" (SDG Indicators Metadata-16-02-03). Data on boys is scarce and underreporting a common pattern; reasons that render comparability across countries and gender problematic.

Target 16.3 ("Promote the rule of law at the national and international levels and ensure equal access to justice for all") focuses on multidimensional aspects of justice and the rule of law, including the quality of government treatment of both victims and perpetrators of violence. Indicator 16.3.1 ("Proportion of victims of violence in the previous 12 months who reported their victimization to competent authorities or other officially recognized conflict resolution mechanisms") measures reported acts of victimization but requires methodological clarification concerning the concept's interpretations, the dimension of violence to be included, or the counting rules for reporting rates. Moreover, comparability and monitoring might be compromised as only 33 countries have at least 1 data point after 2010 for this indicator, and only 28 countries have at least 1 data point between 2000 and 2010 (SDG Indicators Metadata-16-03-01).

Target 16.4 ("By 2030, significantly reduce illicit financial and arms flows, strengthen the recovery and return of stolen assets and combat all forms of organized crime") remains one of the most challenging to measure. For indicator 16.4.1 ("Total value of inward and outward illicit financial flows"), data collection has not yet started. For indicator 16.4.2 ("Proportion of seized, found or surrendered arms whose illicit origin or context has been traced or established by a competent authority in line with international instruments"), data collection started in 2018 but is problematic due to the "underground nature of illicit arms trafficking." Hence indicator 16.4.2 "does not aim at measuring these flows, but rather the efficiency with which the international community combats the phenomenon of illicit arms trafficking" (SDG Indicators Metadata-16-04-02). Both indicators face comparability issues as countries experiencing different types of illicit financial and arms flows collect different data, not easily comparable (SDG Indicators Metadata-1604-01, -16-04-02).

Target 16.5 ("Substantially reduce corruption and bribery in all their forms") is another ambitious target facing comparability and reliability challenges. Indicator 16.5.1 ("Proportion of persons who had at least one contact with a public official and who paid a bribe to a public official or were asked for a bribe by those public officials, during the previous 12 months") is a measure of (active) bribery prevalence. Operationalized as "the percentage of persons who paid at least one bribe," it does not capture the role of public agents in passive bribery, through the solicitation or acceptance of an undue advantage; neither does it capture other forms of abuse of public office and power, such as "grand corruption," nor the transnational dimension of corruption. Additionally, it remains a subjective indicator, derived from household surveys, with all limitations in terms of reliability and representativeness of perceptionbased measures mentioned above. Measuring indicator 16.5.1 faces comparability challenges as only 21 countries have at least 1 data point after 2010, and only 6 countries have at least 1 data point between 2000 and 2009 (SDG Indicators Metadata-16-05-01). Measuring indicator 16.5.2 ("Proportion of businesses that had at least one contact with a public official and that paid a bribe to a public official or were asked for a bribe by those public officials during the previous 12 months") is based on the World Bank's Enterprise Survey, hence data collected remains anchored to the subjective perception and discretion of the business community. Another limitation relates to the comparability of data, as most countries do not have updated information. The data collected is biased towards developing countries as most high-income countries are not covered and the surveys are mostly undertaken in World Bank client countries (SDG Indicators Metadata-16-05-02). 
Target 16.6 ("Develop effective, accountable and transparent institutions at all levels") presents other important governance dimensions to be measured. Indicator 16.6.1 ("Primary government expenditures as a proportion of original approved budget") as a transparency measure attempts to capture the reliability of government budgets. While measures of transparency are available and have largely been privileged even within the SDGs framework, other types of measures have received less attention, as in the case of output measures, citizen-centered measures, or cross-countries measures of state capacity: no data is available for indicator 16.6.2 ("Proportion of population satisfied with their last experience of public services") (SDG Indicators Metadata16-06-02).

Target 16.7 ("Ensure responsive, inclusive and representative decision-making”) faces both conceptual and measurement challenges as there is no internationally estimated data for this target, but only data on the legislative-component of indicator 16.7.1 ("Proportions of positions in national and local institutions, including (a) the legislatures; (b) the public service; and (c) the judiciary), compared to national distributions, by sex, age, persons with disabilities and populations groups"). As an input measure of parliamentary representation its normativity is visible in the claim for the universality of representative democracy. The indicator focuses on descriptive (i.e., parliamentary composition) and not substantive (i.e., the extent parliaments pursue the interests, substantive, of a given population) representation (see SDG Indicators Metadata 1607-01). The measure is normatively biased assuming that parliamentary legitimacy derives only from descriptive political representation mechanisms (hence larger representation, reflecting the social diversity of a nation). It does not consider how inclusiveness in decision-making might be related to other factors. A second limitation for target 16.7 derives from missing data and consensus on the citizen-based perception of inclusive decision-making, as to be captured in indicator 16.7.2 ("The proportion of the population who believe decision-making is inclusive and responsive").
Target 16.8 ("Strengthen the participation in global governance") also presents conceptual challenges: although data is available for indicator 16.8.1 ("Proportion of members and voting rights of developing countries in international organisations"), the operationalization holds limited capacity of capturing real changes in global governance participation. Indicator 16.8 .1 is a measure of formal sovereign equality, concerning voting rights and membership in 11 different international institutions. As a structural indicator, there will be only small changes over time reflecting changes in membership and voting rights.

Target 16.9 (“By 2030, provide legal identity for all, including birth registration") is measured through indicator 16.9.1 ("Proportion of children under 5 years of age whose births have been registered with a civil authority") available for around 167 low-, middle-, and high-income countries. However, monitoring it in the short-run might be challenging as the goal of achieving universal birth registration remains strictly anchored in improving state capacity, especially in those countries where the systematic recording of births remains problematic because of structural and infrastructural reasons.

Target 16.10 ("Ensure public access to information and protect fundamental freedoms, in accordance with national legislation and international agreements") reflects problems of crosscountry consistency. Indicator 16.10.1 ("Number of verified cases of killing, kidnapping, enforced disappearance, arbitrary detention and torture of journalists, associated media personnel, trade unionists and human rights advocates in the previous 12 months") faces comparability challenges as data collected might suffer from underreporting in some instances. Related reliable monitoring depends on the evaluation of long-term changes, as statistical accuracy and underreporting are influenced by various factors at societal level, such as socially constructed discriminations and disadvantages that affect victims' reporting propensity (SDG Indicators Metadata-16-10-01 p. 6), and require more state-capacity efforts to be addressed. 


\section{Future Directions: The Political Economy of Measuring Governance}

As discussed above, measuring and monitoring SDG 16 and its governance goals represent a technical and political challenge. Consequently, while strongly promoting the normative "good governance" approach, concerns emerged about the overarching acceptability, legitimacy, and practical feasibility of existing governance measures, especially regarding the monitoring of the SDGs' governance goal. The adoption of a Western-centered idea of "good governance," ignoring how such views may be "transplanted" in country targets of development aid and assistance, has been widely criticized. The implications of subscribing to Eurocentric avatars (Wallerstein 1997) when measuring and monitoring governance as a development goal need further analysis.

For many low-income countries receiving foreign development assistance, the meaning and measurement of "governance" has been, and often remains, a sensitive issue. The legacy of the 1990s, with Western governments and their aid agencies normatively prescribing their recipes of "good governance" to aid recipients, has left bitter memories. Advanced capitalist economies often presented themselves as having fully achieved "good governance," while sponsoring democratization (mainly in terms of multi-party elections) and trade liberalization policies that have gradually hollowed out the state through reforms of public sectors and bureaucracies. Despite their technocratic and neutral appeal, these policies served foreign policy and commercial interests, while the emphasis on "good governance" has often been at the expense of state capacity and autonomy. For evidence on the negative impact on state capacity in developing economies, see Reinsberg et al. (2019).

Some elements of the "good governance" agenda encapsulated in SDG 16 targets therefore remain problematic. In developing countries of the African continent, this agenda often resulted in "maladjustment" of African economies (Mkandawire 2005) and contributed to the crisis of the state in the periphery of capitalist expansion (Amin 2011) with its associated economic, political, and social distortions, partially in response to international pressures. Western concentration on transparency and anti-corruption goals, often meant that other goals, such as building and increasing state capacity were neglected. In Latin America, public sector reforms as prescribed by donors and investors in the pursuit of economic stability often created weak states, unable to accomplish public administration tasks, and hence to gain legitimacy in the eyes of their population (Alcántara 1998). Emphasis on decentralization and civil society empowerment often contributed to weak central authority favoring protracted dependency on external sources of financing (Alcántara 1998). In African countries, Structural Adjustments Programmes contributed to transforming the postcolonial state into a "managerial" state under IMF/World Bank sponsored reforms, as happened in Ghana (KonaduAgyemang 2001). The "good governance" idiom has hence been criticized for reproducing a developmental dream "entitling the North to develop and democratize the South in its image" (Abrahamsen 2000, p. xi).

Even if a prolific academic debate focuses on the limits of adhering to a Western-centered idea of "good governance" while ignoring how such views may be implemented in developing countries, more research is needed on implications of subscribing to a Eurocentric avatar in measuring and monitoring governance as a development goal. Attention to elements of political economy and geography is particularly significant in this context to understand contestations of existing measures. The UN pushes for better capacitybuilding and data collection and the SDGs Framework "place[s] greater demands on the scientific community" (Lu et al. 2015, p. 432) to provide a globally shared notion of governance. Yet, in light of limited knowledge on the political economy of governance measures, such a technocratic solution will not suffice to overcome existing power and structural inequalities in the making of governance measures that exclude parts of the international community of states from framing the SDG agenda. Who creates, produces, and funds existing measures is essential to understand who frames the implementation of the SDG's 
development agenda. Knowing to what extent the nature of producers and funders influences existing governance measurement helps becoming sensitive to the impact of such inequalities on the monitoring of SDGs governance-related performance and to recognize biases in international norm-setting related to the SDG.

A recent dataset, systematically categorizing and mapping producers and funders of governance indicators (Umbach et al. 2020), suggests the existence of a Global North-Global South divide in the production and use of governance metrics. The majority of existing measures of governance covered by the new dataset are produced in high-income economies, as the producers are based either in North America or Europe. Regardless of where they are located, these producers can institutionally or de facto operate at international level; especially as a growing decentralization has taken place, with a growing number of measures produced by intergovernmental organizations, international NGO, and multinational corporations. As measures are designed in and for a designated and constructed global space, core-periphery hierarchies are visible in the way measures have been used to steer countries with bad governance performances into "the good governance pathway". This geographical distribution of measuring governance is also an indication of hierarchies informing existing metrics and existing power imbalances.

The international division of labor between producers and users of existing measures compromises these measures' acceptability, as their legitimacy does not just depend on the quality of technical assessments, but also on the quality of judgments and normative assumptions supporting them. Benchmarks against which governance performances are measured reflect views of a specific subset of the international community (institutions, experts, NGOs involved in the production). Existing metrics do not reflect a shared notion of "good governance," but rather a hegemonic view based on a Western-centric ideal-type of governance. As the legitimacy of these "global" claims to knowledge and authority in the governance discourse has been increasingly contested, the Statistic Division at the UNDESA responsible for the implementation of the SDG Agenda has attempted to address these issues by improving the inclusiveness of statistical offices as well as national and local institutions in the SDG measurement framework. Yet, measuring SDG 16 targets will potentially continue to be contested, as some of the normative "good governance" assumptions remain unchanged. Gaining better credibility and legitimacy for governance metrics in the next set of development goals might require much more intellectual and policy innovation than simply adjusting ownership of and participation in existing frameworks. Policy- and metrics-makers should be mindful of such challenges and, in the longer-run, work towards globally shared notions of governance and alternative measures.

\section{Cross-References}

- Access to Justice: Promoting the Legal System as a Human Right

$\checkmark$ Capacity Building

- Collaborative Governance

- Contemporary Institutional Autonomy and SDG Implementation: Challenges and Opportunities

- Democracy in Developed Countries

- Democracy in Developing World

- Development Paradigms Related to Peace, Justice, and Solid Institutions: A Case Study on Guatemala for Decision-Makers

$\checkmark$ Fair Elections

- Governance and Regulation

- Institutional Innovation for Sustainability

- International Resistance Networks for Anticorruption: Multi-stakeholder Mechanisms

- Local Governance: From City Government to Good Urban Governance

- Open Government

- Organizational Diversity

> Political Participation

> Political Pluralism

- Recontextualizing SDG Implementation Under Political Instability and Growth of Populism

- Regulatory Capabilities

- Rule of Law and the UN Sustainable Development Goals 
- Suppression of Political Dissent

- Traditional Institutions and Governance: Conflict Mediators or Instigators?

- Transparent Government

- Trust in Governmental Institutions

\section{References}

Abrahamsen R (2000) Disciplining democracy: development discourse and good governance in Africa. Zed Books, London

Amin S (2011) Maldevelopment: anatomy of a global failure, 2nd edn. Pambazuka Press, Cape Town

Andrews M (2008) The good governance agenda: beyond indicators without theory. Oxf Dev Stud 36:379-407

Bhargava V, Little S (2015) Is adoption of governance as a SDG an empty gesture? In: World Bank Blogs. Available via https://blogs.worldbank.org/governance/adop tion-governance-sdg-empty-gesture. Accessed 8 Mar 2020

Bhuta N, Malito DV, Umbach G (2018) Of numbers and narratives- indicators in global governance and the rise of a reflexive indicator culture. In: Malito DV, Umbach G, Bhuta N (eds) The Palgrave handbook of indicators in global governance. Palgrave Macmillan, Basingstoke, pp 1-29

Boese VA (2019) How (not) to measure democracy. Inter Area Stud Rev 22(2):95-127

Börzel TA (2005) European Governance. Markt, Hierarchie oder Netzwerk? In: Schuppert GF, Pernice I, Haltern U (eds) Europawissenschaft. Nomos, BadenBaden, pp 613-641

Cooley A, Snyder J (2015) Ranking the world: grading states as a tool of global governance. Cambridge University Press, New York

Davis KE, Fisher A, Kingsbury B, Merry SE (2012) Governance by indicators: global power through classification and rankings. Oxford University Press, Oxford

de Alcántara CH (1998) Uses and abuses of the concept of governance. Int Soc Sci J 50:105-113

Doornbos M (2001) Good governance: the rise and decline of a policy metaphor? J Dev Stud 37:93-108

Fukuyama F (2013) What is governance? Governance 26:347-368

Galtung F (1998) Criteria for sustainable corruption control. Eur J Dev Res 10(1):105-128

Grindle MS (2004) Good enough governance: poverty reduction and reform in developing countries. Governance 17:525-548

Hajer M, Nilsson M, Raworth K et al (2015) Beyond cockpit-ism: four insights to enhance the transformative potential of the sustainable development goals. Sustainability 7:1651-1660

Holt J, Manning N (2014) Fukuyama is right about measuring state quality: now what? Governance 27:717728
Hulme D, Savoia A, Sen K (2015) Governance as a global development goal? Setting, measuring and monitoring the Post-2015 development agenda. Glob Policy 6:8596

Jachtenfuchs M, Kohler-Koch B (2003) Regieren und Institutionenbildung. In: Jachtenfuchs $\mathrm{M}$, KohlerKoch B (eds) Europäische integration. Leske und Budrich, Opladen, pp 11-46

Joshi DK, Hughes BB, Sisk TD (2015) Improving governance for the Post-2015 sustainable development goals: scenario forecasting the next 50 years. World Dev 70:286-302

Kelley JG, Simmons BA (2014) Politics by number: indicators as social pressure in international relations. Am J Polit Sci 1-16

Konadu-Agyemang K (2001) IMF and World Bank sponsored structural adjustment programs in Africa: Ghana's experience, 1983-1999. Routledge, London

Levi-Faur D (2011) Regulation and regulatory governance, Chapter 1. In: Levi-Faur D (ed) Handbook on the Politics of Regulation. Edward Elgar, Cheltenham

Levi-Faur D (2012) The Oxford handbook of governance. Oxford University Press, Oxford

Lu Y, Nakicenovic N, Visbeck M, Stevance AS (2015) Five priorities for the UN sustainable development goals-comment. Nature 520:432-443

Malito DV (2018) The creative disorder of measuring governance and stateness. In: The Palgrave handbook of indicators in global governance. Palgrave Macmillan, Basingstoke, pp 97-137

Malito DV, Umbach G, Bhuta N (eds) (2018) The Palgrave handbook of indicators in global governance. Palgrave Macmillan, Basingstoke

Merry SE, Davis KE, Kinsburg B (2015) The quiet power of indicators measuring development, corruption, and the rule of law. Cambridge University Press, New York

Mkandawire T (2005) Maladjusted African economies and globalisation. Afr Dev 30:1-33

Reinsberg B, Kentikelenis A, Stubbs T, King L (2019) The world system and the hollowing out of state capacity: how structural adjustment programs affect bureaucratic quality in developing countries. Am J Sociol 124 (4):1222-1257

Rosenau JN, Czempiel EO (1992) Governance without government: order and change in world politics. Cambridge University Press, Cambridge

Rotberg RI (2014) Good governance means performance and results. Governance 27:511-518

Rothstein B (2012) Good governance. In: Levi-Faur D (ed) The Oxford handbook of governance. Oxford University Press, Oxford, pp 143-154

Smith W, Brassett J (2008) Deliberation and global governance: liberal, cosmopolitan, and critical perspectives. Ethics Int Aff 22:69-92

Umbach G (2009) Intent and reality of the European employment strategy: Europeanisation of National Employment Policies and policy-making? Nomos, Baden-Baden 
Umbach G (2017) Measuring (global) governance - the potential, the practical and the problematic assessment of governance within and beyond the state. In: Triandafyllidou A (ed) Global governance from regional cultural perspectives: a critical view. Oxford University Press, Oxford, pp 45-69

Umbach G (2019) Of numbers and narratives: evidence for policy-making in the 21 st century. Paper presented at the 62nd ISI world statistical, Kuala Lumpur, 18-23 August 2019

Umbach G, Malito DV, Savoia A (2020) Dataset on the political economy of measuring state capacity and governance; updated version of Malito DV, Savoia A, Umbach G (2015) Dataset on the political economy of measuring state capacity and governance, Florence/ Manchester
United Nations (ed) (2015) Transforming Our World: the 2030 Agenda for Sustainable Development. A/RES/70/ 1. United Nations, New York

United Nations (2019) The sustainable development goals report 2019. UNSD, New York

United Nations General Assembly (2019) Global indicator framework for the sustainable development goals and targets of the 2030 agenda for sustainable development. E/CN.3/2019/2, Annex II. United Nations, New York

UNSTATS (2020) SDG indicators metadata repository, Metadata on single SDG, https://unstats.un.org/sdgs/ metadata/. Accessed 31 Mar 2020

Wallerstein I (1997) Eurocentrism and its avatars: the dilemmas of social science. Sociol Bull 46:21-39

Zumbansen P (2012) Governance: an interdisciplinary perspective. In: Levi-Faur D (ed) The Oxford handbook of governance. Oxford University Press, Oxford, pp 8496 